Volume 3, Issue 4 October-December 2018, Pages: 272, DOI: http://dx.doi.org/10.19082/ah272

\title{
EVALUATION OF THE ANTI-INFLAMMATORY ACTIVITY OF BIOGLUCUMIN: MIXTURE OF AQUEOUS EXTRACT OF TWO MEDICINAL PLANTS: (HERICIUMERINACEUS AND CURCUMIN) IN VIVO EXPERIMENTAL STUDY IN MICE (NMRI)
}

\author{
Rezkallahzeyneb ${ }^{1}$, Amari Nesrine ${ }^{2}$, Djebli Noureddine ${ }^{1,2}$ \\ zinebrezkallah8@gmail.com,nesrineamari@yahoo.fr
}

1: Depertement of Biology, Faculty of Nature and Health, University of Abd Hamid IbnBadis, Mostaganem, Algeria.

2: Laboratory of Phytotherapy Apipharmacognosy (LPAP), University of Abd Hamid IbnBadis, Mostaganem, Algeria

\section{TYPE OF ARTICLE: CONFERENCE ABSTRACT}

\begin{abstract}
Inflammation is a process used to eliminate the pathogen and repair tissue damage. Many plants and herbs have been shown to exhibit potent anti-inflammatory effects. The present research aims to study the anti-inflammatory effects of a mixture of two medicinal plants: mushroom and curcumin (bioglucumine). The experiments were performed on the model of acute edema of the paw induced by carrageenan mice. The model was tested by aqueous extracts of bioglucomin at dose $100 \mathrm{mg} / \mathrm{kg}$ administered orally. Gavage was performed one hour before induction of acute inflammation with $1 \%$ carrageenan. The results obtained were compared with those of Diclofenac and those of physiological control. After oral administration of physiological saline, carrageenan significantly increased mouse paw volume by $71.97 \pm 15.06 \%, 51.06 \pm 4.46 \%$, and $33.92 \pm 19.46 \%$, respectively for $1 \mathrm{~h}, 3 \mathrm{~h}$ and $6 \mathrm{~h}$. Administration of Diclofenac $(50 \mathrm{mg} / \mathrm{kg}$, oral) significantly prevented the increase in mouse paw volume of $64.77 \pm 26.88 \%, 15.29 \pm 8.37 \%$, and $0.51 \pm 0.59$ respectively for $1 \mathrm{~h}, 3 \mathrm{~h}$ and $6 \mathrm{~h}$ after administration of carrageenan. Oral administration of the aqueous extract of bioglucumin was carried out at the dose of $100 \mathrm{mg} / \mathrm{kg}$ $38.35 \pm 15.67 \% ; 15.32 \pm 5.08 \% ; 0 \pm 0 \%$. The histological study of sections treated with Diclofenac and aqueous extract of bioglucomin $(100 \mathrm{mg} / \mathrm{kg})$ confirm that these treatments have anti-inflammatory activity. In addition, the inflammatory infiltrate disappears almost completely. The results of this study highlight the pharmacological bases of bioglucomin in traditional medicine to prevent inflammatory processes

KEYWORDS: bioglucomin, Mushroom, Curcumin, Anti-inflammatory, Edema, Aqueous extract
\end{abstract}

\footnotetext{
Abstracts of Third International Conference on Health Sciences and Medical Technologies, October 2018, Tlemcen, Algeria (ICHSMT-18)

(C) 2018 The Authors. This is an open access article under the terms of the Creative Commons Attribution-NonCommercialNoDerivs License, which permits use and distribution in any medium, provided the original work is properly cited, the use is non-commercial and no modifications or adaptations are made.
} 